\title{
Faktor-Faktor Yang Mempengaruhi Kunjungan Antenatal Care Terhadap Perilaku Antenatal Care
}

\author{
Puji Astuti Wiratmo $^{1^{*}}$, Lisnadiyanti $^{2}$, Nurkamilia Sopianah $^{3}$ \\ ${ }^{1,2,3}$ FKK Universitas Binawan
}

\begin{abstract}
ABSTRAK
Antenatal care (ANC) merupakan upaya untuk mendeteksi dini terjadinya resiko tinggi pada ibu hamil. Namun masih ditemukan perilaku ketidakpatuhan ANC yang disebabkan oleh beberapa faktor. Penelitian ini bertujuan untuk mengetahui faktor-faktor yang mempengaruhi kunjungan ANC terhadap perilaku ANC di Puskesmas Kecamatan Pasar Rebo Jakarta Timur. Penelitian ini menggunakan desain deskriptif korelasi dengan metode survey CrossSectional. Analisa data menggunakan metode Spearman's rho dengan responden berjumlah 117 orang. Hasil penelitian menunjukkan adanya faktor-faktor yang mempengaruhi kunjungan ANC terhadap perilaku ANC, antara lain usia dengan nilai korelasi $(r=0,419)$, nilai p-value sebesar 0,000; pendidikan dengan nilai korelasi $(r=0,425)$, nilai p-value sebesar 0,000; pekerjaan dengan nilai korelasi $(r=0,279)$, nilai p-value sebesar 0,002; penghasilan dengan nilai korelasi $(r=0,407)$ dengan nilai p-value sebesar 0,000; pengetahuan dengan nilai korelasi $(r=0,409)$, nilai p-value sebesar 0,000; dukungan suami/keluarga dengan nilai korelasi $(r=0,417)$, nilai p-value sebesar 0,000; sikap dengan nilai korelasi $(r=0,597)$, nilai p-value sebesar 0,000 $(<0,05)$. Ketidakteraturan dalam melakukan ANC memberikan dampak buruk bagi ibu hamil karena tidak diketahuinya faktor-faktor resiko yang mungkin terjadi pada ibu dan janinnya dan tidak dapat terdeteksi secara dini penyakit yang diderita oleh ibu hamil. Kesimpulan penelitian ini adalah perawat sebagai petugas kesehatan perlu meningkatkan perannya sebagai pendidik dan pemberi pelayanan pada ibu hamil dan keluarganya tentang pentingnya ANC untuk menurunkan angka kematian ibu dan memantau keadaan janin.
\end{abstract}

Kata kunci: antenatal care; ibu hamil; perilaku ANC; usia; pendidikan

\begin{abstract}
Introduction: Antenatal Care (ANC) is an effort to detect the occurrence of high risk in pregnant women. However, ANC non-compliance was still found due to several factors. Aim of study: This study aims to determine factors that influence ANC visits to ANC behavior at Puskesmas Pasar Rebo East Jakarta. Method: This study used a descriptive correlation design with a cross-sectional survey. Data analysis used Spearman's rho with 117 respondents. Results and Discussion: The results showed that there are some factors that influence ANC visits to ANC behavior, including age with a correlation value $(r=0.419)$, a p-value of 0.000; education with a correlation value $(r=0.425), p$-value of 0.000; jobs with a correlation value $(r=0.279)$, $p$-value of 0.002; income with a correlation value $(r=0.407), p$ value of 0.000; knowledge with a correlation value $(r=0.409)$, p-value of 0.000; husband / family support with a correlation value ( $r=0.417)$, $p$-value of 0.000; attitude with a correlation value $(r=0.597)$, $p$-value of $0.000(<0.05)$. Irregularity in carrying out ANC has a bad impact on pregnant women because they are not aware of the risk factors that may occur to the mother and her fetus and can not be detected early on the disease suffered by pregnant women. Conclusion: The conclusion of this study is nurses as health workers need to increase their role as educators and health care provider to pregnant women and their families about the importance of ANC to reduce maternal mortality and monitor the state of the fetus.
\end{abstract}

Keywords: antenatal care; pregnant mother; ANC behavior; age; education

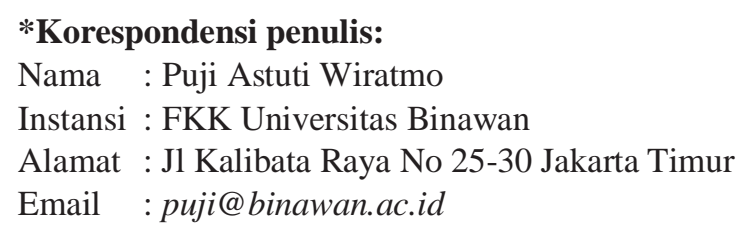




\section{Pendahuluan}

Angka Kematian Ibu (AKI) merupakan salah satu indikator yang peka terhadap kualitas dan aksesibilitas fasilitas pelayanan kesehatan. Kematian yang berkaitan dengan kehamilan merupakan masalah yang sampai saat ini belum dapat diatasi. Hal ini terlihat dari masih tingginya angka kematian yang berkaitan dengan masalah kehamilan, seperti angka kematian ibu (AKI) dan angka kematian bayi (AKB) di berbagai belahan dunia ${ }^{1}$. Berdasarkan data Survei Demografi dan Kesehatan Indonesia (SDKI) tahun 2015 oleh Badan Pelaksana Survei (BPS), AKI di Indonesia adalah 305 kematian per 100.000 kelahiran hidup. Angka ini cukup tinggi karena melebihi target yang telah ditentukan, yaitu 102 kematian per 100.000 kelahiran hidup ${ }^{2}$. Tingginya AKI dapat menunjukkan masih rendahnya kualitas pelayanan kesehatan.

Setiap hari di tahun 2017, sekitar 808 perempuan meninggal akibat komplikasi kehamilan dan persalinan. Penyebab utama kematian ibu adalah perdarahan, hipertensi, infeksi, dan penyebab tidak langsung, terutama yang berkaitan dengan kondisi medis yang sudah ada sebelumnya dan kehamilan ${ }^{3}$. Hampir semua kematian ini terjadi di daerah dengan sumber daya rendah, dan sebagian besar dapat dicegah dengan permeriksaan kehamilan melalui Antenatal Care (ANC) yang teratur. ANC selama kehamilan dilakukan untuk mendeteksi dini masalah-masalah dan resiko tinggi terhadap kehamilan dan persalinan. Sehingga dapat menurunkan angka kematian ibu dengan memantau keadaan janin. Bila tiap wanita hamil memeriksakan kehamilannya melalui ANC maka bila ditemukan masalah atau resiko tinggi yang dapat membahayakan ibu dan janin dapat segera diatasi sebelum berpengaruh tidak baik terhadap kehamilan tersebut. ${ }^{4}$

Di Indonesia, pelayanan antenatal dilakukan paling sedikit 4 kali kunjungan selama masa kehamilan ibu sesuai dengan kebijakan pemerintah yang didasarkan atas ketentuan WHO. Standar waktu pelayanan tersebut dianjurkan untuk menjamin perlindungan terhadap ibu hamil dan atau janin berupa deteksi dini faktor risiko, pencegahan, dan penanganan dini komplikasi kehamilan. ${ }^{2}$

Penilaian terhadap pelaksanaan pelayanan kesehatan ibu hamil dapat dilakukan dengan melihat cakupan K1 dan K4. Cakupan K1 adalah jumlah ibu hamil yang telah memperoleh pelayanan antenatal pertama kali oleh tenaga kesehatan dibandingkan jumlah sasaran ibu hamil di satu wilayah kerja pada kurun waktu satu tahun. Sedangkan cakupan K4 adalah jumlah ibu hamil yang telah memperoleh pelayanan antenatal sesuai dengan standar paling sedikit empat kali sesuai jadwal yang dianjurkan di tiap trimester dibandingkan jumlah sasaran ibu hamil di satu wilayah kerja pada kurun waktu satu tahun. Indikator tersebut memperlihatkan akses pelayanan kesehatan terhadap ibu hamil dan tingkat kepatuhan ibu hamil dalam memeriksakan kehamilannya ke tenaga kesehatan $^{2}$

Berdasarkan Profil Kesehatan Kota Jakarta (2015), cakupan K1 di Kota Jakarta tahun 2015 sebesar $95,75 \%$. Sedangkan pada cakupan K4 mengalami sedikit penurunan yaitu sebesar 87,48\%. ${ }^{5}$ Di Puskesmas Kecamatan Pasar Rebo, dalam rentang waktu bulan Januari 2019 sampai dengan Maret 2019 terdapat 334 ibu hamil yang memeriksakan kandungannya dengan jumlah ibu hamil trimester 2 dan trimester 3 sebesar $145 \mathrm{ibu}$ hamil.

Penyebab tingginya AKI dan AKB salah satunya adalah karena kurangnya perawatan ibu pada saat kehamilan. Hasil Riset Kesehatan Dasar 2010 menunjukkan ibu hamil yang melakukan pemeriksaan kehamilan ke tenaga kesehatan dilaporkan 83,8 persen, masih ada ibu hamil yang tidak memeriksakan kehamilan sebesar 3 persen. Akses ibu hamil yang memeriksakan kehamilan dengan tenaga kesehatan pada trimester 1 (K1-trimester 1) adalah 72,3 persen. Adapun cakupan akses ibu hamil dengan pola 1-1-2 (K4) oleh tenaga

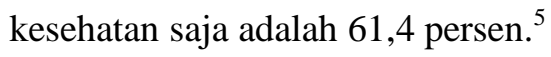

Rodiyatun, dkk (2018) mengidentifikassi beberapa kemungkinan penyebab ketidakteraturan pemeriksaan meliputi faktor ibu (pendidikan, pekerjaan, pengetahuan, riwayat 
kesehatan ibu atau riwayat obstetri), faktor lainnya seperti faktor sosial ekonomi dan budaya. Selain faktor diatas faktor tenaga kesehatan, faktor informasi, faktor pekerjaan, serta sarana dan prasarana termasuk jarak tempuh ke tempat pelayanan kesehatan dari jangkauan sasaran (ibu hamil) turut mempengaruhi perilaku berkaitan dengan pemeriksaan kehamilan. ${ }^{6}$

Penelitian yang dilakukan oleh Fitrayeni, dkk (2015) pada ibu hamil di Puskesmas Pegambiran Padang didapatkan beberapa faktor penyebab rendahnya kelengkapan ANC diantaranya $63 \%$ responden memiliki tingkat pengetahuan rendah, $67,4 \%$ memiliki sikap negatif, $43,5 \%$ responden mengatakan peran bidan kurang baik saat kunjungan, dan 58,7\% responden menyatakan keluarga tidak mendukung. ${ }^{7}$

Dari hasil penelitian oleh (Armaya, 2018) bahwa sebagian besar ibu hamil di wilayah kerja Puskesmas Kota Kutacane Kecamatan Babussalam Kabupaten Aceh Tenggara masih belum patuh dalam melakukan kunjungan Antenatal Care. Beberapa faktor yang signifikan mempengaruhi kepatuhan ibu hamil dalam ANC antara lain usia, sosial ekonomi, pengetahuan, pendidikan, dan dukungan keluarga. ${ }^{8}$ Selain itu, Evayanti (2015) melakukan penelitian pada ibu hamil di di Puskesmas Wates Lampung Tengah dan didapatkan 55\% responden yang kurang teratur melakukan kunjungan ANC. Namun hanya dua variabel saja yang diteliti terkait dengan kujungan ANC dimana kedua fator tersebut yaitu pengetahuan ibu dan dukungan suami menunjukkan hubungan yang signifikan dengan masing-masing nilai $\mathrm{p}$ adalah $\mathrm{p}=0,001$ dan $\mathrm{p}=0,000$. Sehingga penelitian ini menambahkan beberapa variabel lain yang dimungkinkan berhubungan. ${ }^{9}$

Berdasarkan pemaparan dan beberapa penelitian sebelumnya maka penelitian ini mengidentifikasi beberapa faktor lain yang berhubungan dengan kunjungan ANC pada ibu hamil. Tujuan dari penelitian ini adalah untuk mengetahui hubungan faktor-faktor yang mempengaruhi kunjungan ANC terhadap perilaku ANC di Puskesmas Kecamatan Pasar Rebo Jakarta Timur.

\section{Metode}

Penelitian ini menggunakan desain penelitian deskriptif korelasi, menggunakan rancangan penelitian kuantitatif dengan metode penelitian cross-sectional. Populasi pada penelitian ini adalah ibu hamil trimester 2 dan trimester 3 yang berjumlah 145 orang dalam rentang waktu bulan Januari 2019 - Maret 2019 di Puskesmas Kecamatan Pasar Rebo Jakarta Timur. Teknik sampling yang digunakan pada penelitian ini adalah Purposive Sampling dengan kriteria inklusi pada penelitian ini sebagai berikut: a. Ibu hamil trimester II, dan trimester III; b. Ibu hamil yang bisa membaca dan menulis; c. Ibu hamil yang bersedia menjadi responden; $d$. Ibu hamil yang sudah melakukan ANC minimal 1 kali kunjungan. Sebanyak 115 ibu hamil dijadikan sampel dalam penelitian ini. Penelitian ini dilakukan di Puskesmas Kecamatan Pasar Rebo Jakarta Timur pada bulan 12 April 2019 12 Juni 2019.

Setelah mendapatkan persetujuan dari Suku Dinas Kesehatan Jakarta Timur dan mendapatkan izin dari Puskesmas Pasar Rebo, peneliti memulai proses pengambilan data. Peneliti menyeleksi calon responden sesuai dengan kriteria yang telah ditentukan dengan teknik purposive sampling. Pengambilan data dilakukan oleh peneliti sendiri. Peneliti kemudian menjelaskan maksud dan tujuan peneliti kepada responden serta meminta persetujuan responden. Pengisian kuesioner dilakukan kurang lebih selama 10 menit dan peneliti memastikan semua pertanyaan telah terjawab. Selanjutnya peneliti mengobservasi buku KIA milik responden untuk memvalidasi data kunjungan ANC apakah sama atau tidak dengan keterangan yang diisi oleh responden di kuesioner.

Kuesioner yang dipakai pada saat pengambilan data terdiri dari lima bagian. Bagian pertama berisi pertanyaan yang berkaitan dengan karakteristik, bagian kedua berisi pertanyaan yang berkaitan dengan pengetahuan, bagian ketiga berisi pertanyaan yang berkaitan dengan 
dukungan suami, bagian keempat berisi pertanyaan yang berkaitan dengan sikap, bagian kelima berisi pertanyaan yang berkaitan dengan kunjungan ANC yang dilakukan oleh ibu hamil. Uji validitas dan reliabilitas telah dilakukan dengan nilai Cronbach Alpha 0,899. Analisa data yang dilakukan peneliti adalah analisa univariate dan bivariate Uji Korelasi Spearman. Analisis data ini dilakukan dengan program computer SPSS Statistik 17.0.

\section{Hasil dan Pembahasan}

Hasil penelitian dijelaskan berdasarkan distribusi faktor-faktor yang mempengaruhi ANC dan hubungan faktor-faktor yang mempengaruhi ANC terhadap perilaku ANC. Faktor-faktor yang mempengaruhi ANC dalam penelitian ini adalah: usia, tingkat pendidikan, pekerjaan, penghasilan, tingkat pengetahuan tentang ANC, dukungan keluarga terhadap ANC, sikap terhadap ANC dan jumlah kunjungan ANC yang dilakukan. Selanjutnya berbagai faktor tersebut dilakukan Analisa untuk mengetahui sejauhmana pengaruhnya terhadap perilaku ANC.

Pada penelitian diperoleh hasil (Tabel 1) bahwa mayoritas ibu hamil berusia 26-30 tahun (46,2\%), ibu yang memiliki latar belakang pendidikan SMA $(56,4 \%)$, tidak bekerja $(72,6 \%)$, serta memiliki penghasilan Rp 2.000.0003.000 .000 (47\%). Sebagian ibu memiliki tingkat pengetahuan yang baik tentang ANC $(50,4 \%)$. Para ibupun didukung dengan baik oleh suami/keluarga $(93,2 \%)$ dan mereka mempunyai sikap yang positif terhadap ANC (76,1\%).
Tabel 1. Distribusi Faktor-Faktor Yang Mempengaruhi Kunjungan ANC

\begin{tabular}{lcc}
\hline \multicolumn{1}{c}{ Variabel } & $\begin{array}{c}\text { Jumlah } \\
(\mathbf{N})\end{array}$ & $\begin{array}{c}\text { Presentase } \\
(\boldsymbol{\%})\end{array}$ \\
\hline Usia & & \\
\hline $20-25$ tahun & 45 & 38,5 \\
$26-30$ tahun & 54 & 46,5 \\
$31-35$ tahun & 18 & 15,4 \\
\hline Total & 117 & 100 \\
\hline Pendidikan & & \\
\hline SD & 11 & 9,4 \\
SMP & 31 & 26,5 \\
SMA & 66 & 56,4 \\
Perguruan tinggi & 9 & 7,7 \\
\hline Total & 117 & 100 \\
\hline Pekerjaan
\end{tabular}

Pekerjaan

\begin{tabular}{lcc}
\hline Tidak bekerja & 85 & 72,6 \\
Bekerja & 32 & 27,4 \\
\hline Total & 117 & 100 \\
\hline Penghasilan & & \\
\hline Rp. $1.000 .000-$ & 22 & 18,8 \\
2.000 .000 & 55 & 47,0 \\
Rp. $2.000 .000-$ & 31 & 26,5 \\
3.000.000 & 9 & 7,7 \\
Rp. $3.000 .000-$ & & \\
4.000 .000 & & \\
$>5.000 .000$ & & \\
\hline Total & 117 & 100
\end{tabular}

\begin{tabular}{lcc}
\hline Total & 117 & 100 \\
\hline Pengetahuan & & \\
\hline Kurang & 14 & 12,0 \\
Cukup & 44 & 37,6 \\
Baik & 59 & 50,4 \\
\hline Total & 117 & 100 \\
\hline
\end{tabular}

Dukungan

suami/keluarga

\begin{tabular}{lcc}
\hline Tidak mendukung & 8 & 6,8 \\
Mendukung & 109 & 93,2 \\
\hline Total & 117 & 100 \\
\hline Sikap & & \\
\hline Negatif & 28 & 23,9 \\
Positif & 89 & 76,1 \\
\hline Total & 117 & 100 \\
\hline ANC & & \\
\hline Tidak teratur & 20 & 17,1 \\
Teratur & 97 & 82,9 \\
\hline Total & 117 & 100 \\
\hline
\end{tabular}


CoMPHI Journal: Community Medicine and Public Health of Indonesia Journal

Vol. 1, No. 2, Oktober 2020, hlm. 67-76

Tabel 2. Hubungan Faktor-Faktor Yang Mempengaruhi ANC Terhadap Perilaku ANC

\begin{tabular}{|c|c|c|c|c|c|c|c|c|c|}
\hline \multirow{3}{*}{ Variabel } & \multirow{3}{*}{ Kategori } & \multicolumn{4}{|c|}{ Perilaku ANC } & \multirow{2}{*}{\multicolumn{2}{|c|}{ Total }} & \multirow{3}{*}{ p-value } & \multirow{3}{*}{ correlation } \\
\hline & & \multicolumn{2}{|c|}{$\begin{array}{c}\text { Tidak } \\
\text { Teratur }\end{array}$} & \multicolumn{2}{|c|}{ Teratur } & & & & \\
\hline & & $\mathbf{N}$ & $\%$ & $\mathbf{N}$ & $\%$ & $\mathbf{N}$ & $\%$ & & \\
\hline \multirow[t]{3}{*}{ Usia } & $20-25$ tahun & 17 & 14,5 & 28 & 23,9 & 45 & 38,5 & & \\
\hline & 26-30 tahun & 3 & 2,6 & 51 & 43,6 & 54 & 46,2 & 0,000 & 0,419 \\
\hline & 31-35 tahun & 0 & 0,0 & 18 & 15,4 & 18 & 15,4 & & \\
\hline \multirow[t]{4}{*}{ Pendidikan } & SD & 8 & 6,8 & 3 & 2,6 & 11 & 9,4 & & \\
\hline & SMP & 7 & 6,0 & 24 & 20,5 & 31 & 26,5 & 0,000 & 0,425 \\
\hline & SMA & 5 & 4,3 & 61 & 52,1 & 66 & 56,4 & & \\
\hline & PT & 0 & 0,0 & 9 & 7,7 & 9 & 7,7 & & \\
\hline \multirow[t]{2}{*}{ Pekerjaan } & Tidak bekerja & 20 & 17,1 & 65 & 55,6 & 85 & 72,6 & 0,002 & 0,279 \\
\hline & Bekerja & 0 & 0,0 & 32 & 27,4 & 32 & 27,4 & & \\
\hline \multirow[t]{4}{*}{ Penghasilan } & $\begin{array}{l}\text { Rp 1.000.000- } \\
2.000 .000\end{array}$ & 10 & 8,5 & 12 & 10,3 & 22 & 18,8 & & \\
\hline & $\begin{array}{l}\text { Rp 2.000.000- } \\
3.000 .000\end{array}$ & 10 & 8,5 & 45 & 38,5 & 55 & 47,0 & 0,000 & 0,407 \\
\hline & $\begin{array}{l}\text { Rp 3.000.000- } \\
4.000 .000\end{array}$ & 0 & 0,0 & 31 & 26,5 & 31 & 26,5 & & \\
\hline & $>5.000 .000$ & 0 & 0,0 & 9 & 7,7 & 9 & 7,7 & & \\
\hline \multirow[t]{3}{*}{ Pengetahuan } & Kurang & 7 & 6,0 & 7 & 6,0 & 14 & 12,0 & & \\
\hline & Cukup & 11 & 9,4 & 33 & 28,2 & 44 & 37,6 & 0,000 & 0,409 \\
\hline & Baik & 2 & 1,7 & 57 & 48,7 & 59 & 50,4 & & \\
\hline \multirow[t]{2}{*}{$\begin{array}{c}\text { Dukungan } \\
\text { suami/keluarga }\end{array}$} & $\begin{array}{c}\text { Tidak } \\
\text { mendukung }\end{array}$ & 6 & 5,1 & 2 & 1,7 & 8 & 6,8 & 0,000 & 0,417 \\
\hline & Mendukung & 14 & 12,0 & 95 & 81,2 & 109 & 93,2 & & \\
\hline \multirow[t]{2}{*}{ Sikap } & Negatif & 16 & 13,7 & 12 & 10,3 & 28 & 23,9 & 0,000 & 0,597 \\
\hline & Positif & 4 & 3,4 & 85 & 72,6 & 89 & 76,1 & & \\
\hline
\end{tabular}


Pada analisa bivariat di tabel 2 terlihat antara variabel usia dengan perilaku ANC didapatkan nilai $p$-value $=0,000$ dan Correlation 0,419 menunjukkan hubungan yang signifikan atau bermakna dengan korelasi sedang atau cukup tinggi. Usia yang sudah matang akan mempengaruhi pola pikir seorang ibu, sehingga ibu akan patuh dalam perawatan kehamilan. Ibu hamil yang berusia 20 hingga 35 tahun telah masuk dalam rentang usia dewasa awal, dimana ibu mulai mengalami proses kematangan emosional dan mampu menerima informasi dengan baik serta mengambil keputusan yang tepat mengenai perilaku kesehatan seperti manfaat perawatan payudara selama kehamilan, sehingga ibu hamil akan semakin sadar untuk melakukan perawatan kehamilan.

Penelitian serupa dilakukan oleh Ika Fauziyah (2012) dan Ria Armaya (2018) tentang kunjungan ANC pada ibu hamil usia terbanyak adalah usia 21-35 tahun, masing -masing sebanyak 61 orang $(74,4 \%)$ dan 42 orang $(76,4 \%) .^{10,8}$ Menurut Depkes RI (2016) menyatakan bahwa sebaiknya ibu hamil pada umur 20 - 35 tahun, karena masa tersebut merupakan masa yang aman untuk hamil alasanya, mulai umur 20 tahun rahim dan bagianbagian lainya sudah benar-benar siap untuk untuk menerima kehamilan. Pada umur tersebut biasanya wanita sudah merasa siap untuk menjadi ibu. $^{2}$

Pada variabel pendidikan terhadap perilaku ANC didapatkan hasil analisa Spearman's rho p-value 0,000 dengan Correlation 0,425 menunjukkan hubungan yang bermakna dengan korelasi sedang atau cukup tinggi. Penelitian ini sejalan dengan penelitian Gabriela (2014), berdasarkan hasil statistik dengan menggunakan uji Fisher Exact diperoleh nilai $p$-value sebesar $0,026(\mathrm{p}<0,05) .{ }^{11} \mathrm{Hal}$ ini menunjukkan bahwa terdapat hubungan antara status pendidikan ibu dengan kunjungan ANC di Puskesmas Teling Atas Kecamatan Wanea Kota Manado. Penelitian lainya yang menunjukkan hasil yang sama juga dilakukan oleh Resia dkk (2016), berdasarkan hasil statistik dengan menggunakan uji korelasi spearmen rho diperoleh nilai $p$-value sebesar $0,000(\mathrm{p}<0,05)$ atau korelasi $=0,874$, artinya terdapat hubungan yang bermakna kearah positif antara tingkat pendidikan dengan pemeriksaan kehamilan di Puskesmas Tanoyan Kabupaten Bolaang Mongondow. ${ }^{12}$ Menurut peneliti, tingkat pendidikan sangat mempengaruhi seseorang untuk bertindak dan mencari penyebab serta solusi dalam hidupnya. Orang yang berpendidikan tinggi biasanya akan bertindak lebih rasional. Oleh karena itu orang yang berpendidikan akan lebih mudah memerima gagasan baru termasuk dalam pemanfaatan ANC. Pendidikan seseorang sangat berpengaruh terhadap perilaku individu dalam mengambil keputusan dan sikapnya dan berpedoman dari apa yang telah mereka dapatkan melalui proses belajar serta pengalaman yang telah diterimanya. Semakin tinggi pendidikan ibu hamil mana akan semakin mudah dalam menerima pemahaman dan menumbuhkan perilaku yang bermanfaat bagi diri dan bayinya dalam ANC.

Berdasarkan hasil analisis bivariat hubungan pekerjaan ibu hamil terhadap perilaku ANC didapatkan nilai p-value sebesar 0,002 < 0,05 hal ini dapat disimpulkan bahwa terdapat hubungan antara pekerjaan ibu terhadap perilaku ANC namun dengan nilai $r=0,279$ yang artinya menunjukan adanya hubungan dengan korelasi lemah/rendah. Penelitian ini sejalan dengan penelitian Kurniawaty (2016), berdasarkan uji Chi-Square didapat $p$-value $=0,016(\rho<0,05)$ menunjukan ada hubungan antara pekerjaan terhadap kunjungan antenatal care. ${ }^{13}$ Namun penelitian Mira dkk (2014), berdasarkan hasil uji Chi-Square menunjukkan nilai $\rho$ value $=0,561(\mathrm{p}$ $<0,05)$ menunjukan tidak terdapat hubungan pekerjaan dengan Antenatal Care (ANC) karena dengan kurangnya kesibukan akan membuat ibu lebih rajin ketempat pelayanan. ${ }^{14}$ Begitu juga dengan penelitian yang dilakukan oleh Lumempouw (2016) di Puskesmas Kota Manado, berdasarkan hasil analisis Fisher Exact diperoleh $p$-value sebesar 0,757 menunjukkan tidak ada hubungan antara pekerjaan ibu dengan kunjungan antenatal care. Hal tersebut dikarenakan hampir sebagian besar ibu yang tidak bekerja sebagai Ibu 
Rumah Tangga sehingga mereka memiliki banyak waktu luang untuk melakukan kunjungan antenatal care. ${ }^{15}$

Hasil analisa Spearman's rho menunjukan hubungan yang signifikan antara penghasilan terhadap perilaku ANC ( $p$-value 0,000) dengan korelasi sedang (Correlation 0,407). Penelitian ini sejalan dengan penelitian Annisa dkk (2017) berdasarkan uji statistic dengan menggunakan Chi-Square didapat $p$ value $=0,004(\mathrm{p}<0,05)$ menunjukan ada pengaruh yang signifikan antara pendapatan keluarga terhadap pelayanan ANC pada ibu hamil di wilayah kerja Puskesmas Mokoau Kecamatan Kambu Kota Kendari. ${ }^{16}$ Begitu juga dengan penelitian Lumempouw (2016) berdasarkan uji Chi-Square menunjukkan nilai $\rho=0,003$. Nilai $\rho$ ini lebih kecil dari nilai $\alpha(0,05)$ ini artinya terdapat hubungan hubungan antara pendapatan ibu hamil dengan ANC. ${ }^{17}$ Faktor penghasilan keluarga mempunyai pengaruh yang signifikan terhadap pelaksanaan antenatal care. Rendahnya pendapatan keluarga meningkatkan hambatan untuk mendapatkan prioritas kesehatan dalam urutan lebih tinggi dari pada prioritas kebutuhan pokok sehingga memperlambat atau menyebabkan terabaikannya frekuensi antenatal care. ${ }^{17}$

Pada analisa hubungan pengetahuan ibu hamil terhadap perilaku ANC di puskesmas kecamatan Pasar Rebo Jakarta timur didapatkan nilai $p$-value sebesar $0,000<0,05$ menunjukkan adanya hubungan dengan korelasi sedang/cukup tinggi $(r=0,409)$. Pengetahuan mempunyai hubungan yang sangat dekat dengan perilaku individu, karena pengetahuan merupakan salah satu ukuran dan indikator dari perilaku kesehatan (Nur Inayah, 2013). ${ }^{18}$ Hasil penelitian yang di lakukan oleh Mardiyah, (2014) dengan judul Faktor yang Berhubungan dengan Pemanfaatan Pelayanan Antenatal oleh Ibu Hamil di Wilayah Kerja Puskesmas Tempurejo Kabupaten Jember menunjukkan bahwa pengetahuan $(\mathrm{p}=0.031$, phi $=0,262)$ memiliki hubungan terhadap pemanfaatan pelayanan antenatal. ${ }^{19}$ Penelitian ini sejalan dengan penelitian Rita (2018), berdasarkan uji Chi-Square didapat p-value= $0,003(\rho<0,05)$ terdapat hubungan signifikan antara pengetahuan dengan kepatuhan kunjungan ANC. Mengacu pada hasil uji statistik tersebut dapat dijelaskan semakin baik pengetahuan ibu hamil maka akan lebih tinggi kemungkinan untuk patuh melakukan kunjungan antenatal care di Puskesmas Kota Kutacane. ${ }^{8}$ Dari hasil penelitian yang ditemukan di puskesmas kecamatan Pasar Rebo Jakarta timur bahwa ibu hamil yang memiliki pengetahuan baik akan sering melakukan pemeriksaan kehamilan (ANC), karena ibu sangat mengetahui apa manfaat dari melakukan ANC dan dengan dilakukannya ANC responden dapat mengetahui kondisi kesehatan ibu dan janinnya.

Berdasarkan hasil analisis hubungan dukungan suami/keluarga ibu hamil terhadap perilaku ANC di puskesmas kecamatan Pasar Rebo Jakarta Timur didapatkan nilai $p$-value sebesar $0,000<0,05$ menunjukkan adanya hubungan antara dukungan suami/keluarga ibu hamil terhadap perilaku ANC dengan nilai $r=$ 0,417 menunjukan korelasi sedang/cukup tinggi. Penelitian ini sejalan dengan penelitian Fasya (2017) berdasarkan uji Chi-Square didapat $p$ value $=0,001(\mathrm{p}<0,05)$ menunjukan ada hubungan antara dukungan suami terhadap Kunjungan antenatal care. $^{20}$ Kemudian penelitian Wulandatika (2017) berdasarkan hasil uji Chi-Square menunjukkan nilai $(\mathrm{p}=0,035)$ menunjukan terdapat hubungan dukungan suami yang bermakna dalam kunjungan antenatal care. ${ }^{4}$ Hasil penelitian dari Gita (2015) ditemukan dari 20 responden tidak mendapatkan dukungan suami, sebanyak 10 responden (50\%) tidak teratur dalam pemanfaatan pelayanan antenatal dan dari 29 responden dengan dukungan suami yang memadai, sebanyak 15 responden $(51,7 \%)$ teratur dalam pemanfaatan pelayanan antenatal. Penelitian tersebut menunjukkan ada hubungan signifikan antara dukungan suami dengan pemanfaatan pelayanan antenatal ( $p$-value $=$ $0,02) .{ }^{21}$ Dukungan suami sebagai orang terdekat sangat diperlukan bagi ibu hamil berupa dukungan motivasi, ketenangan dan kenyamanan serta pemenuhan kebutuhan material ibu hamil. Suami yang mendukung sepenuhnya kehamilan 
istrinya akan memberikan dukungan positif termasuk memotivasi dan bahkan menemani istrinya melakukan ANC yang bermanfaat bagi kesehatan istrinya dan calon anaknya.

Pada variabel sikap ibu hamil terhadap perilaku ANC di puskesmas kecamatan Pasar Rebo Jakarta timur menunjukkan adanya hubungan $(p$-value $0,000<0,05)$ dengan nilai $\mathrm{r}=$ 0,597 menunjukan hubungan dengan korelasi sedang/cukup tinggi. Hasil penelitian ini sejalan dengan penelitian Zulfitria dkk (2017), berdasarkan uji statistic didapat $p$-value $=0,000$ $(\rho<0,05)$ didapatkan bahwa ada hubungan yang signifikan antara sikap ibu dengan pemanfaatan pelayanan $\mathrm{ANC}^{22}$ Hal ini dapat disimpulkan bahwa jika ibu memiliki sikap yang baik maka akan berdampak juga pada pemanfaatan pelayanan ANC. Penelitian ini sejalan dengan penelitian Mira dkk (2014), berdasarkan uji ChiSquare didapat $p$-value $=0,039 \quad(\mathrm{p}<0,05)$ menunjukan adanya hubungan yang signifikan antara sikap ibu hamil dengan kelengkapan ANC. ${ }^{14}$ Adanya sikap yang lebih baik terhadap ANC mencerminkan kepedulian ibu hamil akan kesehatannya dan bayi yang dikandungnya.

\section{Kesimpulan}

Ketidakteraturan dalam melakukan pemeriksaan ANC dikategorikan teratur dan tidak teratur, hal ini dikarenakan oleh faktorfaktor yang mempengaruhi kunjungan ANC, yaitu usia, pendidikan, pekerjaan, penghasilan, pengetahuan, dukungan suami/keluarga, dan sikap. Ketidakteraturan dalam melakukan ANC akan membawa dampak buruk bagi ibu hamil karena tidak diketahuinya faktor-faktor resiko yang mungkin terjadi pada ibu dan janinnya dan tidak dapat terdeteksi secara dini penyakit yang diderita oleh ibu hamil selama masa kehamilan. Hasil penelitian ini didapatkan beberapa faktor yang berhubungan signifikan dengan perilaku kunjungan ANC ibu hamil. Faktor tersebut antara lain usia, pendidikan, pekerjaan, penghasilan, pengetahuan, dukungan suami dan sikap ibu hamil terhadap ANC.

Menanggapi hal tersebut maka penting bagi profesi keperawatan untuk turut andil dalam meningkatkan kesehatan ibu dan bayi. Hal pertama yang harus diperhatikan adalah mengenai sikap dan kesiapan perawat dalam memberikan pelayanan serta mengatasi permasalahan yang muncul. Sikap dan kesiapan sebagaimana disebutkan diatas yaitu rasa empati, tanggung jawab, keterampilan, dan pengetahuan. Tanggung jawab perawat dalam mengatasi hal tersebut adalah dalam hal peningkatan pengetahuan pada ibu hamil tentang manfaat dan pentingnya ANC sesuai dengan peran perawat sebagai educator. Selain memberikan edukasi, perawat juga harus memberikan motivasi bagi ibu hamil untuk selalu melakukan pemeriksaan antenatal demi kesehatan ibu dan janinnya. Namun perawat tidak akan dapat melaksanakan hal tersebut jika tidak ada faktor pendukung bagi ibu hamil dalam keterlibatan pasangan ataupun keluarganya. Support system dari suami/keluarga sangat penting bagi ibu hamil, dan tentunya dapat meningkatkan kesadaran akan pentingnya melakukan pemeriksaan antenatal secara teratur untuk mencegah AKI.

\section{Ucapan Terima Kasih}

Penulis mengucapkan terima kasih kepada para pihak yang telah memberi dukungan dan kontribusi terhadap penelitian ini khususnya Puskesmas Kecamatan Pasar Rebo Jakarta Timur.

\section{Referensi}

1. Suniarti, Nurhayani, Arifin M. Analisis Faktor Yang Berhubungan Dengan Keteraturan Pemanfaatan Antenatal Care (K1-K4) Di Wilayah Kerja Puskesmas Mamasa [Internet]. 2013 May [cited 2020 Sep 1]. Available from: https://core.ac.uk/download/pdf/25492070.p df.

2. Kementerian Kesehatan Republik Indonesia. Profil Kesehatan Indonesia 2016 [Internet]. 2017 Jul [cited 2020 Sep 1]. Available from: https://pusdatin.kemkes.go.id/resources/dow nload/pusdatin/profil-kesehatanindonesia/Profil-Kesehatan-Indonesia2016.pdf. 
3. Trends in maternal mortality 2000 to 2017 : estimates by WHO, UNICEF, UNFPA, World Bank Group and the United Nations Population Division. Geneva: World Health Organization; 2019.

4. Wulandatika D. Faktor-Faktor Yang Berhubungan Dengan Kepatuhan Ibu Dalam Melakukan Kunjungan Antenatal Care Di Wilayah Kerja Puskesmas Gambut Kabupaten Banjar, Kalimantan Selatan Tahun 2013. J Ilmu Keperawatan dan Kebidanan [Internet]. 2017 [cited 2020 Sep 1];8(2):8. Available from: http://dx.doi.org/10.26751/jikk.v8i2.269.

5. Kementerian Kesehatan Republik Indonesia. Riset Kesehatan Dasar Tahun 2010 [Internet]. 2010 Dec [cited 2020 Sep 1]. Available from: http://kesga.kemkes.go.id/images/pedoman/ Riskesdas\%202010\%20Nasional.pdf.

6. Laili AN, Rachmawati VA. Pengaruh Budaya Patriarki Terhadap Keteraturan Pemeriksaan Kehamilan Pada Ibu Hamil Di Wilayah Puskesmas Bangkalan. Embrio: Jurnal Kebidanan [Internet]. 2018 May [cited 2020 Sep 1];10(1):13-19. Available from: https://doi.org/10.36456/embrio.v10i1.1433.

7. Fitrayeni F, Suryati S, Faranti RM. Penyebab Rendahnya Kelengkapan Kunjungan Antenatal Care Ibu Hamil Di Wilayah Kerja Puskesmas Pegambiran. J Kesehat Masy Andalas [Internet]. 2017 Okt [cited 2020 Sep 1];10(1):101. Available from: http://jurnal.fkm.unand.ac.id/index.php/jkma /article/view/170/165.

8. Armaya R. Kepatuhan Ibu Hamil dalam Melakukan Kunjungan Antenatal Care dan Faktor yang Mempengaruhi. J Ilmu Kesehat Masy. [Internet]. 2018 Mar [cited 2020 Sep 1];7(01):43-50. Available from: https://doi.org/10.33221/jikm.v7i01.51.

9. Evayanti Y. Hubungan Pengetahuan Ibu Dan Dukungan Suami Pada Ibu Hamil Terhadap Keteraturan Kunjungan Antenatal Care (ANC) Di Puskesmas Wates Lampung Tengah Tahun 2014. J Kebidanan [Internet]. 2015 Jul [cited 2020 Sep 1];1(2):81-90.
Available from: https://doi.org/10.33024/jkm.v1i2.550.

10. Priani IF. Faktor-Faktor yang Mempengaruhi Keteraturan Ibu Hamil Melakukan Antenatal Care di Puskesmas Cimanggis Kota Depok [Skripsi]. Depok: Universitas Indonesia; 2012.

11. Lumempouw GA, Pelealu FJO, Maramis FRR. Hubungan Antara Pengetahuan, Status Pendidikan, Dan Status Pekerjaan Ibu Dengan Kunjungan Antenatal Care Di Puskesmas Teling Atas Kecamatan Wanea Kota Manado [Internet]. 2015 [cited 2020 Sep 1]. Available from: https://fkm.unsrat.ac.id/wpcontent/uploads/2014/10/JURNALPENELITIAN-geby.pdf.

12. McAllister M. STAR: A Transformative Learning Framework for Nurse Educators. J Transform Educ. [Internet]. 2012 Jan [cited 2020 Sep 1];9(1):42-58. Available from: https://doi.org/10.1177\%2F1541344611426 010.

13. Kurniawaty. Faktor-Faktor Yang Berhubungan Dengan Kunjungan ANC di Bidan Praktik Mandiri Hj. Maimunah Kertapati Palembang. Gaster [Internet]. 2018 Feb [cited 2020 Sep 1];16(1):36-48. Available from: https://jurnal.aiskauniversity.ac.id/index.php/gaster/article/vie $\mathrm{w} / 235$.

14. Dewi MK, Widarini W, Karmaya NM. Hubungan Karakteristik Sosial Ekonomi dan Dukungan Suami dengan Kelengkapan Antenatal Care (ANC) di Puskesmas Denpasar Selatan III. Public Heal Prev Med Arch. [Internet]. 2014 Jul [cited 2020 Sep 1];2(1):45. Available from: https://doi.org/10.15562/phpma.v2i1.122

15. Lumempouw VJR, Kundre R, Bataha Y. Hubungan Faktor Sosial Ekonomi Ibu Hamil Dengan Keteraturan Pemeriksaan Antental Care (ANC) Di Puskesmas Ranotana Weru Kecamatan Wanea Kota Manado. J Keperawatan [Internet]. 2016 Nov [cited 2020 Sep 1];4(2):107657. Available from: https://ejournal.unsrat.ac.id/index.php/jkp/ar 
ticle/view/14075/13651.

16. Khotimah AR, Dupai L, Saktiansyah LOA. Faktor yang Mempengaruhi Pemanfaatan Pelayanan Antenatal Care di Wilayah Kerja Puskesmas Mokoau Kecamatan Kamu Kota Kendari Tahun 2016. J Ilm Mhs Kesehat Masy. [Internet]. 2017 Nov [cited 2020 Sep 1];2(8):1-8. Available from: http://dx.doi.org/10.37887/jimkesmas.v2i8.3 897.

17. Umayah RF. Hubungan Tingkat Ekonomi Ibu Hamil dan Tingkat Kepuasan Dengan Keteraturan Pemeriksaan Kehamilan Di RB \& BP ASY-SYIFA' PKU Muhammadyah Wedi Klaten [Skripsi]. Solo: Universitas Sebelas Maret; 2010.

18. Rauf NI, Amir MY, Balqis. Faktor yang Berhubungan dengan Pemanfaatan pelayanan Antenatal Care Di Puskesmas Minasa Upa Kota Makassar Tahun 2013 [Internet]. 2013 [cited 2020 Sep 1]. Available from:

https://core.ac.uk/download/pdf/25490837.p df.

19. Mardiyah UL, Herawati YT, Witcahyo E. Faktor yang Berhubungan dengan Pemanfaatan Pelayanan Antenatal oleh Ibu Hamil di Wilayah Kerja Puskesmas Tempurejo Kabupaten Jember Tahun 2013 ( Correlated Factors of Antenatal Services Utilization by Pregnant Women at Community Health Center of Tempurejo. eJurnal Pustaka Kesehatan [Internet]. 2014 Jan [cited 2020 Sep 1];2(1):58-65. Available from:

https://jurnal.unej.ac.id/index.php/JPK/articl e/view/597.

20. Nabilah F, Daryanti MS, Sugiyanto S. Hubungan Dukungan Suami Dengan Keteraturan Antenatal Care (ANC) Pada Ibu hamil trimester III di BPM Istri Utami Sleman Yogyakarta [Skripsi]. Yogyakarta: Universitas 'Aisyiyah; 2017.

21. Sari GN, Fitriana S, Anggraini DH. Faktor Pendidikan, Pengetahuan, Paritas, Dukungan Keluarga dan penghasilan Keluarga yang Berhubungan Dengan Pemanfaatan
Pelayanan Antenatal. J Ilmu dan Teknol Kesehat. [Internet]. 2015 Mar [cited 2020 Sep 1];2 Nomor 2(1):77-82. Available from: http://ejurnal.poltekkesjakarta3.ac.id/index.p $\mathrm{hp} / \mathrm{jitek} /$ article/view/93/72.

22. Zulfitria Z, Yuniar N, Yunawati I, Kesehatan F, Universitas M, Oleo H. Faktor Yang Berhubungan Dengan Pemanfaataan pelayanan antenatal Care pada Ibu Hamil di Wilayah Kerja Puskesmas mawasangka Tengah kabupaten buton Tengah Tahun 2017. J Ilm Mhs Kesehat Masy. [Internet]. 2017 Aug [cited 2020 Sep 1];2(7):1-10. http://dx.doi.org/10.37887/jimkesmas.v2i7.3 432. 